\title{
Audit committee support and auditor independence
}

\begin{abstract}
This study investigates whether audit committee do contribute towards external auditor independence. Audit committees are mandatory internal control mechanism required in all listed firms to ensure effective enforcement of good corporate governance. The results indicate that auditor independence is positively associated with audit committee meetings, audit committee report in the annual report, roles to approve and review audit fees, and composition of audit board. These results are consistent with the spirit of corporate governance code that was designed, among others, to improve the quality of financial reporting and hence increase confidence in the information presented in the reports.
\end{abstract}

Keyword: Audit committee; Auditor independence; Bursa Malaysia; Perceptions; Compliance 